УДК 004:78:005.921.1- 022.324: [002.1:37]

Іванова Світлана Миколаївна

кандидат педагогічних наук, завідувач відділу відкритих освітньо-наукових інформаційних систем Інститут інформаційних технологій і засобів навчання НАПН України, м. Київ, Україна

iv-svetlana@yandex.ua

\title{
ІНФОРМАЦІЙНО-АНАЛІТИЧНА ПІДТРИМКА НАУКОВО-ПЕДАГОГІЧНИХ ДОСЛІДЖЕНЬ (ЗАРУБІЖНИЙ ТА ВІТЧИЗНЯНИЙ ДОСВІД)
}

\begin{abstract}
Анотація. У статті розглянуто вітчизняний і зарубіжний досвід інформаційно-аналітичної підтримки науково-педагогічних досліджень. Описано та охарактеризовано структуру інформаційно-аналітичної підтримки Інституту інформаційних технологій і засобів навчання Національної академії педагогічних наук України. Визначено, що інформаційноаналітична підтримка науково-педагогічної діяльності науково-дослідних установ має забезпечувати формування бази даних; систематизацію та збереження основних інноваційних розробок науково-педагогічних досліджень; виявлення перспективних напрямів наукових досліджень; моніторинг науково-педагогічних досліджень; оприлюднення та розповсюдження наукової продукції; вільний доступ до електронних освітніх ресурсів.
\end{abstract}

Ключові слова: інформаційно-аналітична підтримка; науково-педагогічні дослідження; моніторинг науково-педагогічних досліджень.

\section{1. ВСТУП}

Однією з основних умов успішної реалізації державної політики у сфері розвитку інформаційного суспільства відповідно до «Стратегії розвитку інформаційного суспільства в Україні», що схвалена розпорядженням Кабінету Міністрів України від 15 травня 2013 року № 386-р [1], є забезпечення навчання, виховання, професійної підготовки, підвищення кваліфікації та навчання впродовж життя особистості для професійної діяльності в інформаційному середовищі. Одним з головних пріоритетів розвитку вітчизняної психолого-педагогічної науки $є$ підвищення ефективності наукових досліджень і використання їх результатів для забезпечення розвитку освітньої галузі України. На законодавчому рівні цей процес відзначено в Законах України «Про затвердження Національної стратегії розвитку інформаційного суспільства в Україні на 2006-2015 роки», «Про наукову і науково-технічну діяльність», «Про інноваційну діяльність», «Про заходи щодо забезпечення пріоритетного розвитку освіти в Україні», «Про Національну доктрину розвитку освіти України в XXI столітті, «Про Концепцію Національної програми інформатизації», Національному проекті «Відкритий світ», Національній стратегії розвитку освіти в Україні на період до 2021 року щодо інформатизації освіти за напрямом розроблення та впровадження інформаційноаналітичних технологій. Важливим стає інформаційно-аналітична підтримка (IAпідтримка) навчально-виховного процесу системи освіти наукової, науковопедагогічної, освітньої діяльності.

Постановка проблеми. Постійно підвищуються вимоги щодо підвищення якості, продуктивності та результативності педагогічних досліджень. 3 огляду на вищевикладене, актуальним стає використання інформаційно-комунікаційних технологій (IKT) для IA-підтримки педагогічних досліджень. Методи збирання, зберігання, передачі та аналітичної обробки даних, що використовувалися раніше, вже не можуть забезпечити нагальних потреб науки та освіти. Тому аналіз, підбір та 
визначення систем IА-підтримки педагогічних досліджень на основі електронних систем відкритого доступу є одним із пріоритетних завдань, що вимагають вирішення.

Аналіз останніх досліджень і публікацій. ІА-підтримка науково-педагогічної діяльності для їі продуктивності $\epsilon$ проблемою досліджень вітчизняних дослідників В. Ю. Бикова, О.В.Новицького, В. А. Резніченка, О.М.Спіріна, М. А. Шиненка, А. В. Яцишин та ін., зарубіжних учених Діміркен Г. (Haluk Demirkan), Ділін Д. (Dursun Delen), Цзяньго Ч. (Jianguo Chen), Хао Ч. (Haо Chen) та ін.

Основний акцент цих досліджень спрямовано на виокремлення таких IКТ, що дозволяють підтримувати та поповнювати електронні освітні ресурси, що представлені в електронних наукових бібліотеках; отримувати аналітичні дані щодо впровадження наукових продуктів; забезпечувати проведення онлайн-конференцій та вебінарів та ін.

Метою статті $\epsilon$ проаналізувати зарубіжний і вітчизняний досвід щодо створення інформаційно-аналітичної підтримки науково-педагогічних досліджень та описати структуру інформаційно-аналітичної підтримки Інституту інформаційних технологій i засобів навчання НАПН України.

\section{2. МЕТОДИ ДОСЛІДЖЕННЯ}

Дослідження виконується в рамках науково-дослідної роботи (НДР) «Система інформаційно-аналітичної підтримки педагогічних досліджень на основі електронних систем відкритого доступу» (2015-2017рр.) ДР №0115U002234.

Для розв'язання завдань, поставлених у НДР використані загальнонаукові методи: аналіз та узагальнення вітчизняного та зарубіжного досвіду використання інформаційно-аналітичної підтримки науково-педагогічних досліджень на основі електронних систем відкритого доступу, зокрема: відкритих журнальних систем, наукових електронних бібліотек та їх інформаційно-аналітичних сервісів, створених на програмному забезпеченні EPrints, сервісів Google: (Google Scholar, Google Analytics, Google Apps та ін.), платформ для проведення вебінарів та відкритих конференційних систем, систематизація та узагальнення теоретичних даних: описано структуру інформаційно-аналітичної підтримки Інституту інформаційних технологій і засобів навчання НАПН України.

\section{3. РЕЗУЛЬТАТИ ДОСЛІДЖЕННЯ}

Науковці Цзяньго Ч. та Хао Ч. [2], аналізуючи вимоги щодо підтримки наукової діяльності у сучасному суспільстві, виокремлюють проблему автоматизації управління наукової діяльності, рішення якої має позитивно вплинути на якість наукових досліджень та забезпечить їх IA-підтримку. Вони пропонують систему IA-підтримки, що включає в себе такі чотири функціональні модулі:

- управління традиційними науковими роботами, під якими розуміються наукові статті, що складаються з назви, відомостей про авторів, анотації, ключових слів, викладу змісту дослідження, висновків та списку використаної літератури;

- управління та генерація навчальних матеріалів і правил їх екстракції; модуль для управління і вивантаження наукових матеріалів до системи;

- управління багатовимірними (англ. multidimensional papers) роботами, під якими розуміються збірники наукових праць, посібники, монографії та ін.;

- тестування наукової продукції, що передбачає аналіз статистичних даних щодо завантаження наукових робіт за певною темою, певним автором, ключовими словами, зображеннями та ін. 
Дослідники Г. Діміркен та Д. Ділін [3] вважають, що IA-підтримку діяльності будь-якої установи, зокрема наукової, забезпечують сервіс-орієнтовані системи підтримки прийняття рішень (англ. service-oriented decision support systems (DSS in cloud).

Середовище, яке науковці створюють для підтримки прийняття рішень, орієнтовано на: підбір ІКТ як таких, що надають різні можливості щодо діяльності у середовищі; процеси, що допомагають у прийнятті рішень; запити і вимоги користувачів; специфіку організації в якості посередника. Виходячи 3 цього, вони запропонували структуру ІА-підтримки різних професійних сфер діяльності користувачів. Ця структура включає в себе: дані як послугу (англ. Data-as-a-service (DaaS), інформацію як послугу (англ. Information-as-a-service (IaaS), аналітику як послугу (англ. Analytics-as-a-service (AaaS). Вчені виокремлюють DaaS та IaaS як різні послуги, оскільки вкладають у них різний зміст, що відображено на схемі структури IAпідтримки різних професійних сфер діяльності користувачів [3] (рис. 1).

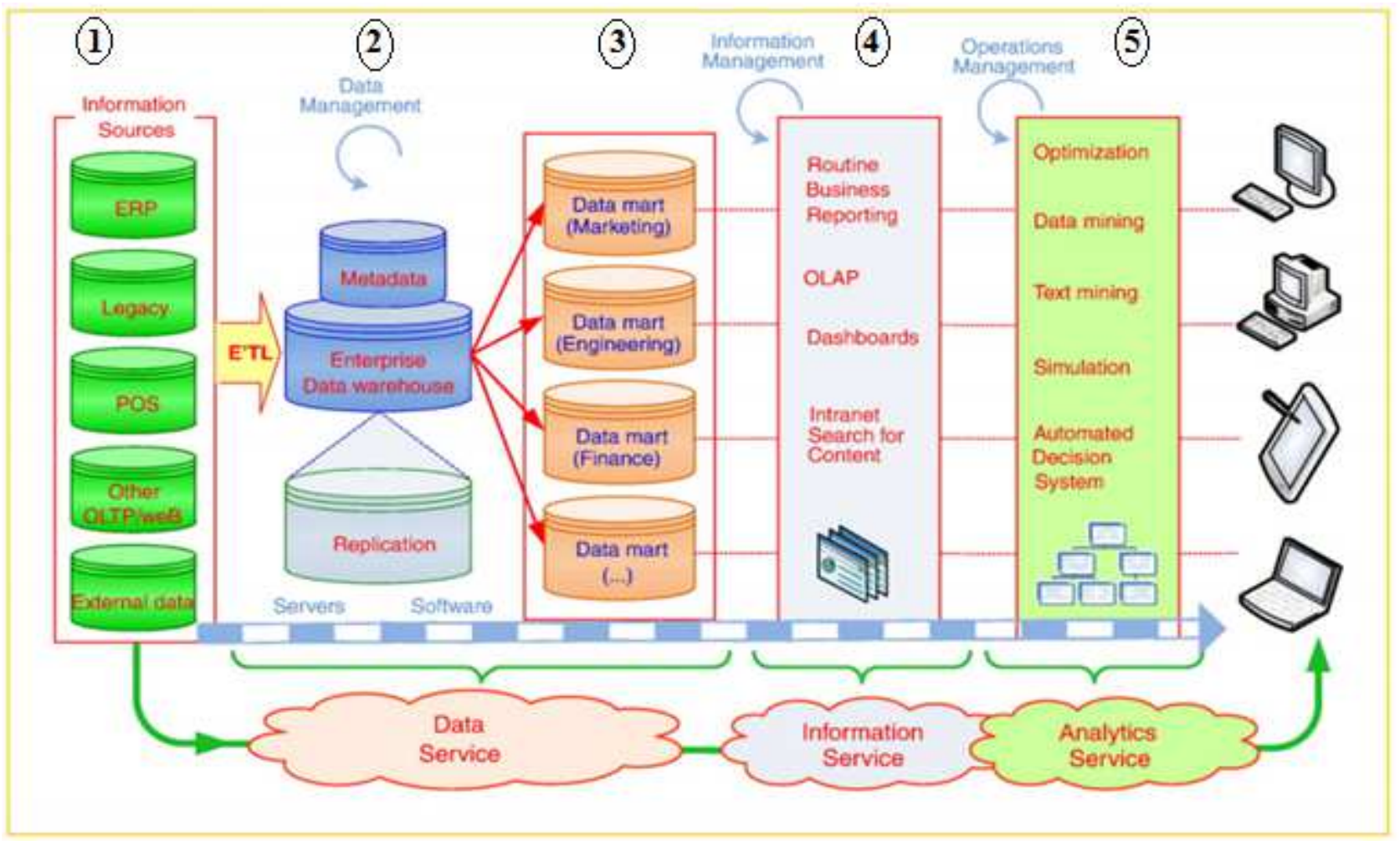

Рис.1. Структура ІА-підтримки різних професійних сфер діяльності користувачів [3]

На рисунку 1 зображено п’ять блоків: перший - «Джерела інформації» (англ. Information Sources); другий - «Управління даними» (англ. Data Management); третій блок розкриває зміст управління даними; четвертий - «Управління інформаційними ресурсами» (англ. Information Management); п'ятий - «Управління операціями» (англ. Operations Management). Перші три блоки забезпечують DaaS, четвертий - IaaS, п'ятий - AaaS.

Розглянемо вищезазначені блоки структури IA-підтримки різних професійних сфер діяльності користувачів відповідно до дослідження Г. Діміркена та Д. Діліна [3]. 
Перший блок включає в себе такі елементи: систему управління ресурсами організації (англ. Enterprise Resource Planning System (ERP); доробок (англ. Legacy); місце продажу різної продукції (англ. Point of sale (POS); онлайн обробку трансакцій як один із способів організації бази даних (англ. Online Transaction Processing (OLTP) та зовнішні дані (англ. External Data). Перший блок є відображенням основних джерел інформації, які забезпечують DaaS. Цей блок пов'язаний із наступним блоком управління відомостями через такі процеси як вилучення, перетворення, завантаження (англ. Extract,Ttransform, Load (ETL) відомостей та даних.

Другий блок «Управління даними» включає в себе метадані, сховище корпоративних даних (англ. Enterprise Data Warehouse), копіювання цих даних (англ. Replication).

У третьому блоці відображені процеси, що відбуваються 3 метаданими та сховищем корпоративних даних для їх розповсюдження, а саме: експортування та імпортування даних; технічне забезпечення; фінансування та ін.

Четвертий блок вміщує аналітичну обробку відомостей та даних у реальному часі (англ. Online Analytical Processing (OLAP) 3 метою надання більш доступної та відкритої інформації для користувача.

П'ятий блок - оптимізація та перевірка даних на актуальність відповідно до статистичного аналізу щодо їх завантаження та використання користувачами.

Зображена на рис.1 структура IА-підтримки різних професійних сфер діяльності користувачів, може бути адаптована для проведення науково-педагогічних досліджень.

Вітчизняні дослідники А. В. Васильєв, В. В. Хоменко, В. О. Любчак, Ю. М. Коровайченко, Д. В. Фільченко [4], проаналізувавши різні аспекти побудови інтегрованої інформаційної системи управління вищим навчальним закладом, запропонували структуру IA-підтримки вищого навчального закладу, створивши іiі на базі веб-системи Сумського державного університету. Вони виокремили шість основних складових, що можуть забезпечити ефективне вирішення повсякденних завдань управління університетом, а саме: інформаційно-аналітична складова управління університетом; інформаційно-бібліотечна складова університету; інформаційна складова електронного навчання; інформаційна складова тестування; інформаційна складова електронного документообігу; складова, що базується на вебсервісах та являє собою складну розгалужену інформаційну мережу.

Центральним елементом веб-системи університету є головний веб-сайт, завдяки якому забезпечується вільне поширення інформації про всі види його діяльності. Загальна іiі структура складається 3 веб-сайтів та інформаційних сервісів: веб-сайти університету; веб-сайти, що відображають діяльність університету і знаходяться у домені та піддоменах, що зареєстровані за університетом.

Для забезпечення функціонування веб-системи університету, вченими [4] визначаються вісім категорій тих, хто здійснює ії підтримку:

- керівник веб-системи, який відповідає за розробку концепції, узгодження розвитку, контроль побудови веб-системи як складової єдиної інтегрованої інформаційної системи університету;

- відповідальний за розробку архітектури та принципи побудови веб-системи згідно з ії концепцією розвитку, забезпечення побудови, розвитку та інтеграції цієї системи у єдину інформаційну систему університету;

- відповідальний за нормативно-методичне забезпечення системи, за розробку та узгодження нормативно-методичного забезпечення веб-системи згідно 3 ii концепцією розвитку, архітектури та принципів іiі побудови, забезпечення функціонування та проведення аналізу її ефективності; 
- адміністратор веб-системи, який відповідає за комплексне функціонування вебсайтів та інформаційних сервісів у складі системи, забезпечення захисту інформації та координацію діяльності адміністраторів сайтів, проведення комплексного аналізу статистики відвідувань і підготовку рекомендацій щодо покращання стану веб-сайтів у мережі Інтернет;

- відповідальний за тематичний напрям, за розробку та узгодження структури управління контентом тематичного напряму згідно з нормативно-методичними вимогами та забезпечення відображення відповідної інформації на веб-сайті 3 максимальним використанням інформаційних сервісів;

- відповідальний за розділ контенту, що включає своєчасне надання, узгодження та оприлюднення інформації, контроль іiі достовірності та відповідності нормативно-методичним вимогам і забезпечення коректного відображення інформації на веб-сайті;

- адміністратор веб-сайту, який відповідає за функціонування та супроводження сайта, його просування у пошукових системах, аналіз статистики відвідувань та забезпечення захисту інформації;

- веб-майстер, який відповідає за фактичне розміщення, видалення та редагування контенту сайту згідно з дорученнями відповідальних за тематичні напрями та розділи контенту.

Слід звернути увагу на структуру IA-підтримки, що пропонують дослідники для управління діяльністю університету в мережі Інтернет (рис. 2).

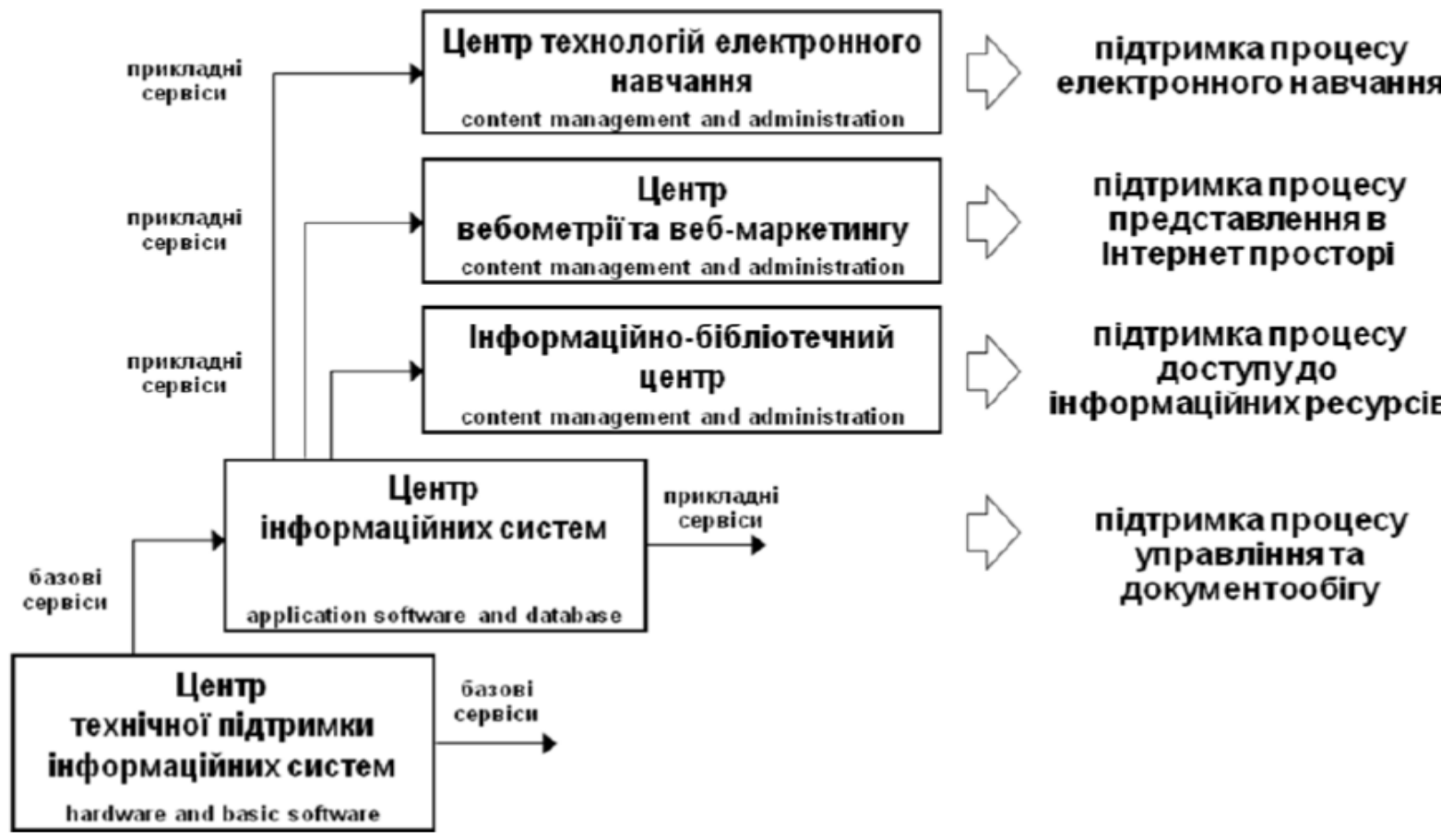

Рис. 2. Структура ІА-підтримки для управління діяльністю університету в мережі Інтернет [4] 
На рисунку 2 дослідники виділяють чотири основні процеси, що потребують IAпідтримки у мережі Інтернет, а саме: електронне навчання; представлення та аналіз ресурсів в Інтернет просторі; доступ до інформаційних ресурсів; управління та документообіг.

Слід відмітити, що для створення IA-підтримки наукової діяльності, зокрема науково-педагогічних досліджень, важливим $є$ рішення таких завдань:

- формування бази відомостей та даних для ведення наукової діяльності;

- систематизація та збереження основних інноваційних розробок науковопедагогічних досліджень;

- виявлення перспективних напрямів наукових досліджень;

- оцінювання науково-педагогічних досліджень відповідно до розвитку суспільства;

- моніторинг наукової продукції;

- обмін науковими відомостями та даними, що охоплює оприлюднення, розповсюдження та використання наукової продукції (статей, монографій, посібників та ін., виступів на конференціях, вебінарах, форумах та ін.);

- забезпечення вільного доступу до відомостей та даних для проведення наукових досліджень.

Метою розробки IA-підтримки наукових досліджень будь-якої установи, зокрема науково-дослідної, є створення єдиного інформаційно-аналітичного середовища, що забезпечить можливість накопичення, ведення, оприлюднення, розповсюдження, моніторингу наукової продукції та вільного доступу до неї науковців.

3 огляду на це, інформаційно-аналітична підтримка науково-педагогічних досліджень є системою, що забезпечує за допомогою IКТ, наукових працівників необхідними відомостями для проведення науково-дослідної діяльності, інструментарієм для аналізу якісних і кількісних показників щодо оприлюднення, розповсюдження та використання наукової продукції, зберігає іiі конфіденційність, цілісність, доступність та ін. [5].

IA-підтримка науково-педагогічних досліджень на основі електронних систем відкритого доступу складається зі статистичних, інформаційно-аналітичних наукометричних сервісів: відкритих журнальних систем, побудованих на платформі OJS, наукових електронних бібліотек, побудованих на платформі EPrints, програм, що надають можливість перевірки ресурсів на плагіат, eTXT, платформ для проведення вебінарів та конференцій, системи моніторингу веб-сайтів Google Analytics. Основними критеріями добору електронних систем відкритого доступу $\epsilon$ : їх відкритість, функціональність та придатність до використання в наукових установах та навчальних закладах України [5].

Структура IA-підтримки науково-педагогічних досліджень Інституту інформаційних технологій і засобів навчання НАПН України (IITЗН НАПН України) охоплює всі вище зазначені сервіси (рис.3), крім маркетингу наукових продуктів (експортування та імпортування даних, технічне забезпечення цього процесу; фінансування та ін.) [3] та електронного навчання [4], що у IA-підтримки науковопедагогічних досліджень ІІТЗН НАПН України забезпечується тільки частково, а саме, через вебінари та Інтернет-конференції. 


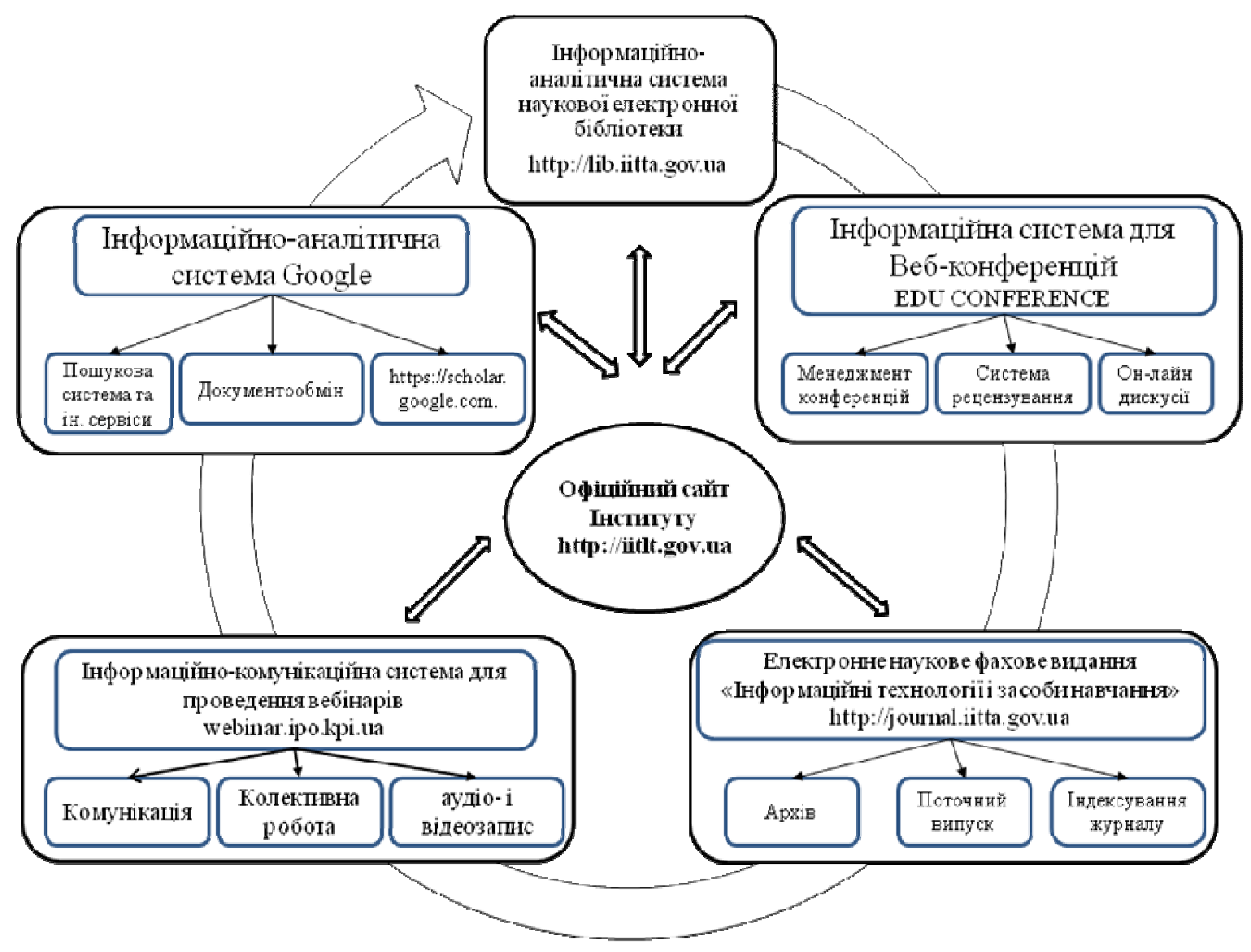

Рис. 3. Структура ІА-підтримки науково-педагогічних досліджень Інституту інформачійних технологій $і$ засобів навчання НАПН України

Розглянемо компоненти IA-підтримки науково-педагогічних досліджень IITЗН НАПН України детальніше.

Центральним компонентом структури IA-підтримки науково-педагогічних досліджень є офіuійний caŭm Iнcmumymy (http://iitlt.gov.ua), до якого інтегровано всі інші компоненти структури, а саме: інформаційно-аналітична система наукової електронної бібліотеки (http://lib.iitta.gov.ua) «Електронна бібліотека НАПН України» (англ. Digital Library of the National Academy of Educational Sciences of Ukraine); інформаційна система для веб-конференцій EDU CONFERENCE (conf.iitlt.gov.ua); електронне наукове фахове видання «Інформаційні технології і засоби навчання» (http://journal.iitta.gov.иa) (англ. Information Technologies and Learning Tools); інформаційно-комунікаційна система для проведення вебінарів (для проведення яких, наприклад, використовується вітчизняний сервіс http://webinar.ipo.kpi.ua); інформаційно-аналітична система Google.

Розкриємо зміст цих компонентів докладніше.

Інформаційно-аналітична система наукової електронної бібліотеки «Електронна бібліотека НАПН України» дозволяє, на основі застосування розподілених бібліотечних інформаційних мереж, завантаження ресурсів (розповсюдження), цитування наукової продукції (використання), захист публікацій від плагіату; забезпечує відкритий доступ до результатів педагогічних досліджень; прискорює цикл дослідження та процес цитування публікацій; сприяє інтеграції України до єдиного світового інформаційно-освітнього простору; зменшує наукову ізоляцію вітчизняної 
наукової спільноти; забезпечує можливість оперативного пошуку потрібного цифрового контенту [6].

Основні сервіси Електронної бібліотеки [7]:

- навігація за ресурсами, що надають інформаційні сервіси електронної бібліотеки, забезпечує сервісами пошуку та перегляду;

- сервіси перегляду, які допомагають переглянути ресурси за їхніми характеристиками, що містяться в сховищі електронної бібліотеки, а саме: за роком видання, темою класифікатора, науковими установами, автором, темою;

- сервіси реєстрації користувачів, що передбачають внесення користувачем основних даних про нього як автора електронних ресурсів бібліотеки;

- сервіси авторизації користувача передбачають функції входу-виходу користувачів у електронну бібліотеку, керування профілем користувача та зміни паролю, реєстрацію нових користувачів, функції відновлення втрачених аутентифікаційних даних;

- сервіси депонування ресурсів зареєстрованих користувачів, управління ними депозитами, обліковим записом і збереженням пошуків.

- сервіси імпорту та експорту ресурсів між електронними бібліотеками, що забезпечується за допомогою програмного забезпечення EPrints;

- пошукові сервіси електронної бібліотеки, які забезпечують простий та розширений пошук електронних ресурсів бібліотеки, а також завантаження користувачем цих ресурсів, не залежно від його статусу (зареєстрований або незареєстрований у електронній бібліотеці).

Для забезпечення ефективної IA-підтримки науково-педагогічних досліджень важливим $\epsilon$ вміння наукових співробітників користуватися вищезазначеними сервісами. Особливого значення набувають сервіси депонування ресурсів зареєстрованих користувачів, управління ними депозитами, обліковим записом, оскільки правильне внесення метаданих ресурсу забезпечить його відображення у бібліотеці та правильне цитування відповідно до бібліографічних даних наукового продукту. Для цього налагоджено оперативне консультування користувачів бібліотеки (консультації он-лайн, електронне листування з розсилкою інструктивних матеріалів, консультації за мобільним зв'язком та ін.).

Інформаційна система для веб-конференцій EDU CONFERENCE підтримує проведення Інтернет-конференцій. Вона включає наступні сервіси:

- менеджмент конференцій, що дозволяє створювати, організовувати онлайнконференції та вебінари різних рівнів складності;

- архів конференцій, що забезпечує відкритий доступ до матеріалів конференцій;

- система рецензування, що дозволяє оцінювати матеріали доповідей, проводити подвійне сліпе рецензування статей, приймати чи відхиляти матеріали;

- система, що дозволяє проводити онлайн-дискусії, обговорення статей та доповідей у письмовому та відео-режимі;

- система пошуку, що надає можливість знайти необхідну конференцію за ії назвою, датою та місцем проведення.

За кілька років ІІТЗН НАПН України набув досвіду проведення конференцій із використанням цієї системи, зокрема: «I-III Всеукраїнська науково-практична конференція молодих учених «Наукова молодь» (2013-2015 роки), «Звітна науковопрактична конференція Інституту інформаційних технологій і засобів навчання НАПН України» (2015-2016 роки) [8].

Електронне наукове фахове видання «Інформаційні технології $і$ засоби навчання» (http://journal.iitta.gov.ua/index.php/itlt) $є$ рецензованим педагогічним часописом, присвяченим проблемам використання інформаційно-комунікаційних технологій в 
системі освіти. Згідно Наказу Міністерства освіти і науки України №1411 від 10.10.2013, журнал внесено до «Переліку наукових фахових видань України». Тематика: IКТ навчання, IКТ підтримки педагогічних досліджень, IКТ управління в освіті, комп'ютерно-орієнтовані засоби навчання. Журнал «Інформаційні технології і засоби навчання» включено до нової реферативної бази даних PKP Index, створеної у 2016 році ініціативою Public Knowledge Project - розробником такого вільнопоширюваного програмного забезпечення, як Open Monograph Press, Open Conference Systems ma Open Journal Systems, на базі якої функціонує електронне видання Інституту. Особливістю PKP Index є використання протоколу збереження метаданих OAI-PMH, завдяки чому реферати статей потрапляють у базу одразу після публікації кожного випуску журналу. Цей журнал використовує систему Open Journal Systems 2.4.7.1 $(O J S)$ - програмний пакет з відкритим вихідним кодом, який обслуговує процеси менеджменту та публікації журналу. Пакет розробляється, підтримується та вільно розповсюджується Public Knowledge Project на умовах ліцензії GNU General Public License.

Завдяки системі $O J S$, забезпечуються такі сервіси:

- реєстрація авторів та створення їх особистих акаунтів;

- пошук та розширений пошук за автором, назвою статті, анотацією, ключовими словами, датою публікації та ін.;

- збереження архівів журналу;

- інтерактивна довідкова підтримка користувачів журналу;

- всебічна індексація (індексація досліджень, статей, номерів журналів та ін.);

- процес рецензування публікації, від представлення матеріалів до їх публікації та індексації.

Важливим компонентом IA-підтримки науково-педагогічних досліджень $\epsilon$ інформаційно-комунікаиійна система для проведення вебінарів.

Інформаційно-комунікаційна система для проведення вебінарів - це Інтернеттехнологія, що надає можливість проводити онлайн семінари, практичні заняття в віртуальному класі, інтерактивні лекції, опитування, тренінги та ін., за допомогою засобів аудіо- , відео- обміну даними та спільної роботи з різноманітними об'єктами, незважаючи на те, що його учасники можуть фізично знаходитися в різних місцях [9].

Існує велика кількість веб-сервісів, що надають інструменти для IА-підтримки вищезазначеної наукової та навчальної діяльності. Серед таких сервісів набули популярності [10]: BigBlueButton, Google Hangouts, Join.me, MeetingBurner, Mikogo, WebHuddle, Zoho Meeting, Zoom.

Для проведення вебінарів у ІІТЗН НАПН України використовується сервіс, що надає Український інститут інформаційних технологій в освіті НТУУ "Київський політехнічний інститут" (УІІТО) http://webinar.ipo.kpi.ua [11]. Цей сервіс, при реєстрації на сайті webinar.ipo.kpi.ua., надає можливості публікації опису вебінару у персональному кабінеті його організатора, реєстрації вебінару у календарі та повідомлення учасникам щодо його проведення, розміщення та створення презентацій для доповідей, проведення вебінару у призначений час та здійснення аналізу після його завершення.

Важливим елементом IA-підтримки науково-педагогічних досліджень $\epsilon$ електронні бібліометричні системи (ЕБС), за допомогою яких здійснюється формування джерельної бази наукової продукції, опублікованої за результатами науково-педагогічних досліджень (НПД), та статистичне опрацювання і подання бібліометричних показників. Слід відмітити, що бібліометричні системи автоматично визначають індекси цитування праць науковця або колективу науковців та надають можливість ранжувати відповідні індекси, що дозволяє вважати ЕБС одним із засобів 
оцінювання науково-педагогічної діяльності [12]. Використання цих систем як засобу інформаційно-аналітичної підтримки науково-педагогічних досліджень відкриває нові можливості оцінювання значення електронних освітніх ресурсів (ЕОР) для сучасного суспільства, публікаційної активності науковців, рівня ефективності їх наукової діяльності; дозволяє фіксувати рівень актуальності науково-дослідних робіт, тем, публікацій та ін. наукової продукції через аналіз значень показників ЕБС.

Зазначимо, що інформаційно-аналітична система Google Scholar, в якій створено профіль Інституту (https://scholar.google.com.ua/citations? user $=4$ LC3o$8 A A A A J \& h l=u k \&$ authuser=1), дозволяє відслідковувати індекси наукових публікацій співробітників та дані щодо їх цитування (рис. 4).

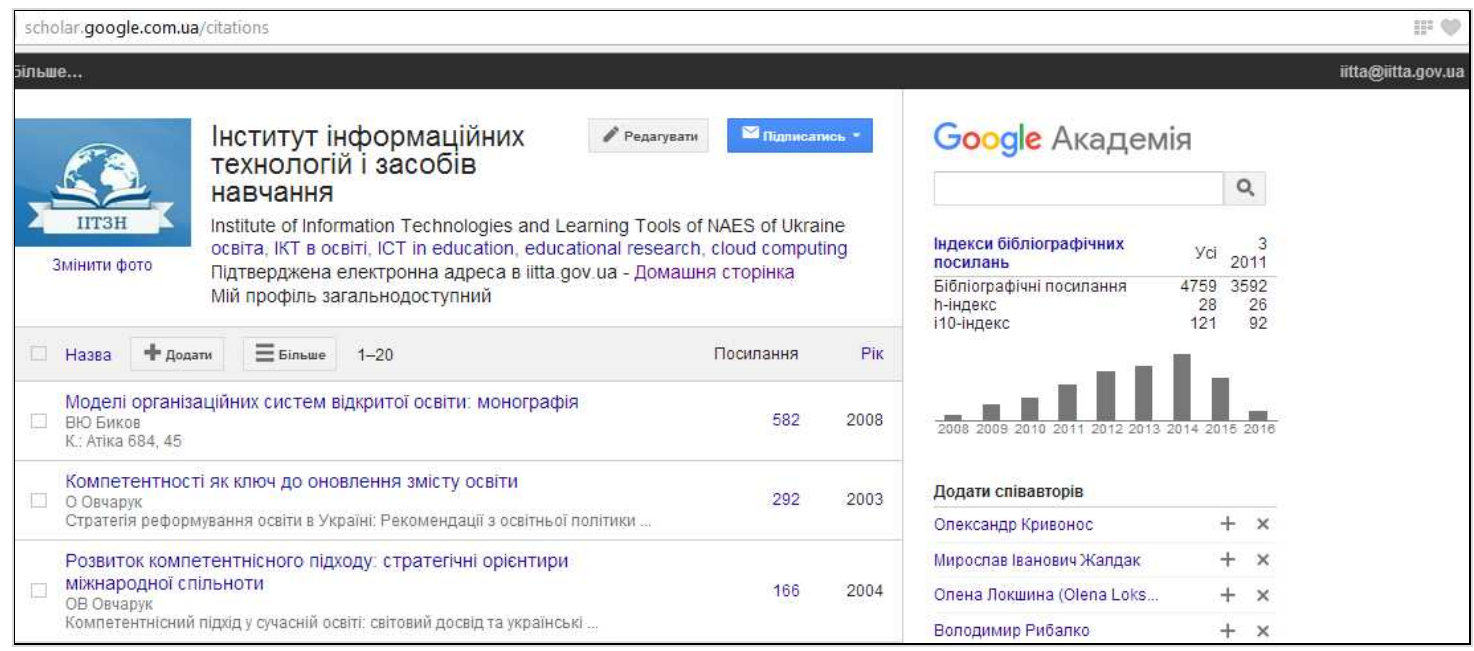

Рис. 4. Фрагмент сторінки профілю Інституту інформащійних технологій $i$ засобів навчання НАПН Украӥни у системі Google Scholar

Крім вищезазначеного, реєстрація профілю Інституту спрощує процедуру моніторингу діяльності наукової установи України у системі Бібліометрики української науки (http://www.nbuviap.gov.ua/bpnu/index.php?page_sites=top_100_journals), оскільки рейтингування наукових установ проводиться, загалом, відповідно до показників, що отримуються з їх профілів у Google Scholar (рис.5). За відсутності профілів у Google Scholar рейтингування наукових установ проводиться за допомогою спеціалізованої програми Publish or Perish.

Важливим компонентом ІА-підтримки науково-педагогічних досліджень $є$ сервіс Google Analytics. В Інституті проводиться моніторинг використання інформаційноаналітичної системи наукової електронної бібліотеки «Електронна бібліотека НАПН України» та електронного наукового фахового видання «Інформаційні технології і засоби навчання» за допомогою сервіса Google Analytics. Моніторинг використання сайту Електронної бібліотеки НАПН України здійснюється за такими показниками: огляд відвідувачів, демографія відвідувачів, поведінка відвідувачів на сайті електронної бібліотеки, технології відвідування сайту, мобільні пристрої, трафік та інші. Моніторинг допомагає збирати, переглядати і аналізувати дані щодо відвідування сайту електронної бібліотеки, дає змогу довідатися, яка середня кількість переглядів сторінок, зміст яких матеріалів дозволяє домогтися найбільшого числа відвідувань та iн. 


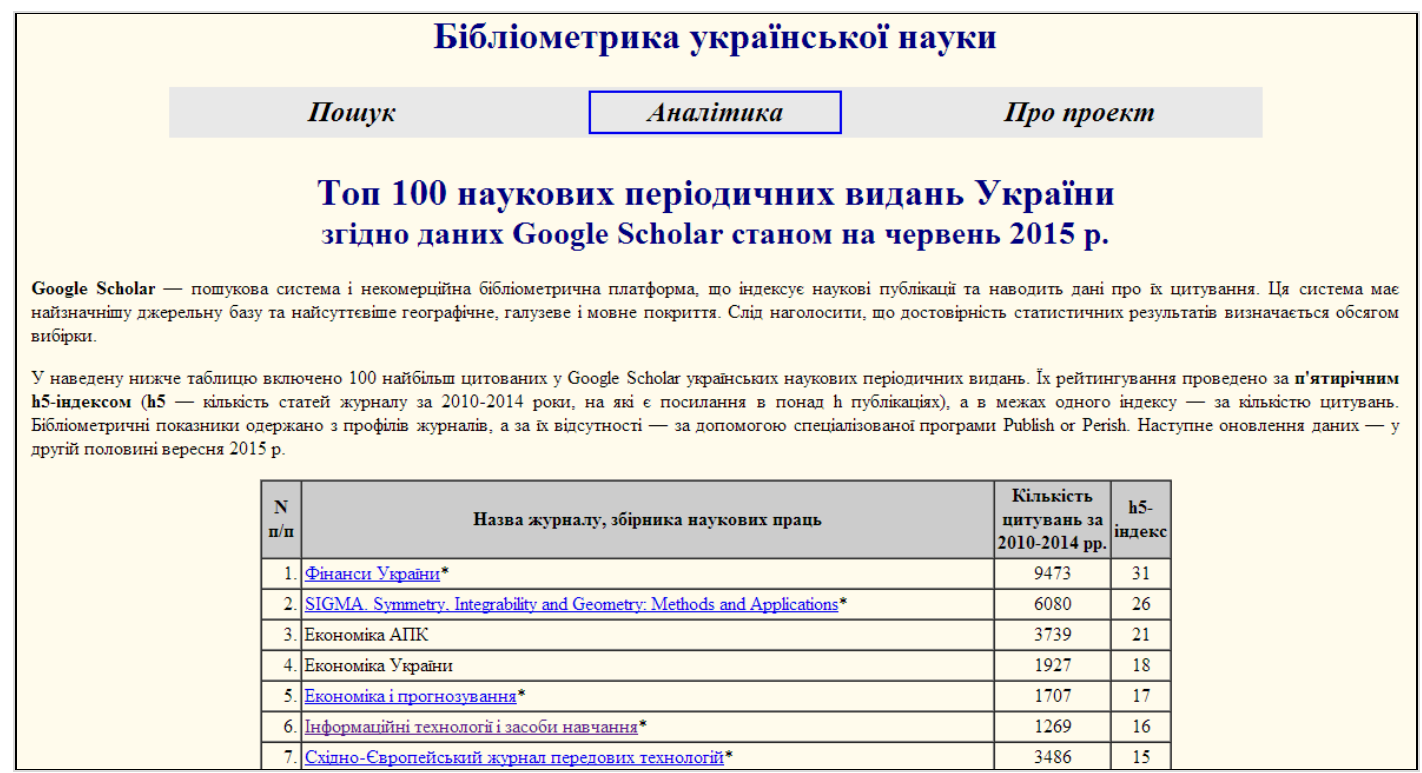

Рис.5. Фрагмент сторінки сайту Бібліометрика украӥнської науки

У структурі IA-підтримки науково-педагогічних досліджень щодо використання продуктів Google варто виокремити сервіси документообігу (Google Drive, Google Docs, Google Apps та ін.), що активно використовуються, наприклад, для сумісної роботи наукових керівників та аспірантів Інституту.

\section{4. ВИСНОВКИ ТА ПЕРСПЕКТИВИ ПОДАЛЬШИХ ДОСЛІДЖЕНЬ}

Вищезазначені компоненти IA-підтримки науково-педагогічних досліджень Інституту (інформаційно-аналітична система наукової електронної бібліотеки «Електронна бібліотека НАПН України»; інформаційна система для проведення Інтернет-конференцій; електронне наукове фахове видання «Інформаційні технології і засоби навчання»; інформаційно-комунікаційна система для проведення вебінарів, інформаційно-аналітична система Google та інші бібліометричні системи) є основними для забезпечення наукової діяльності співробітників, але не вичерпують подальшого ії розвитку.

Отже, IA-підтримка науково-педагогічної діяльності науково-дослідних установ має забезпечувати: формування бази даних для ведення науково-дослідної діяльності співробітників; систематизацію та збереження основних інноваційних розробок науково-педагогічних досліджень; виявлення перспективних напрямів наукових досліджень; моніторинг науково-педагогічних досліджень відповідно до розвитку суспільства; обмін науковими відомостями, що включає оприлюднення, розповсюдження та використання наукової продукції; вільний доступ до ЕОР для проведення наукових досліджень.

Відповідно до цього основними компонентами IА-підтримки науковопедагогічних досліджень мають бути інформаційно-аналітична система наукової електронної бібліотеки, інформаційна система для проведення Інтернет-конференцій; електронне наукове фахове видання; інформаційно-комунікаційна система для проведення вебінарів, бібліометричні системи, що забезпечують індексування наукових публікацій співробітників інституту. 
Перспективою дослідження $€$ розширення діяльності щодо міжнародної презентації наукового доробку Інституту інформаційних технологій і засобів навчання НАПН України.

\title{
СПИСОК ВИКОРИСТАНИХ ДЖЕРЕЛ
}

1. Стратегія розвитку інформаційного суспільства в Україні. Схвалено розпорядженням КМУ від 15 травня 2013 p. № 386-p. [Електронний ресурс] - Режим доступу: http://zakon0.rada.gov.ua/laws/show/386-2013-p.

2. Chen J. Structured Information Extraction Algorithm for Scientific Papers based on Feature Rules Learning / J. Chen, H. A. Chen // Journal of Software, Vol. 8, No. 1, January 2013. - Pp. 55-62.

3. Dursun Delen. Leveraging the capabilities of service-oriented decision support systems: Putting analytics and big data in cloud / Dursun Delen, Demirkan Haluk // Decision Support Systems 55. - 2013. - Pp. $412-421$

4. Інформаційно-аналітична підтримка діяльності університету: інтегрована інформаційна система: монографія / А. В. Васильєв, В. В. Хоменко, В. О. Любчак, Ю. М. Коровайченко, Д. В. Фільченко. - Суми: Сумський державний університет, 2013. - 126 с.

5. Іванова С. М. Інформаційно-аналітична підтримка наукової діяльності в галузі педагогічних наук / С. М. Іванова // Інформаційні технології і засоби навчання. - 2015. - Т. 49, вип. 5. - С. 165-175. [Електронний ресурс] - Режим доступу: http://nbuv.gov.ua/UJRN/ITZN_2015_49_5_15

6. Іванова С. М. Наукова електронна бібліотека НАПН України як засіб інформаційно-аналітичної підтримки педагогічних досліджень / С. М. Іванова // Комп’ютер у школі та сім’ї. - 2015 - № 6 C. $38-43$.

7. Спірін О. М. Досвід впровадження електронної бібліотеки Національної академії педагогічних наук України / О. М. Спірін,С. М. Іванова // Український педагогічний журнал. - 2015. - № 1. - С. 192-205.

8. Яцишин А. В. Досвід застосування системи EDU Conference для інформаційної підтримки наукових масових заходів у галузі педагогічних наук [Електронний ресурс] / А. В. Яцишин // Звітна наукова конференція Інституту інформаційних технологій і засобів навчання НАПН України: Матеріали наукової конференції. - Київ: ІІТЗН НАПН України, 2016. - Режим доступу : http://conf.iitlt.gov.ua/Conference.php?h_id=12

9. Морзе Н. В. Методичні особливості вебінарів, як інноваційної технології навчання / Н. В. Морзе, О.В. Ігнатенко // Інформаційні технології в освіті : збірник наукових праць. - Херсон : Видавництво ХДУ, - 2010. - № 5. - С. 31-39. [Електронний ресурс]. - Режим доступу : http://ite.kspu.edu/en/issue-5/p-31-39

10. Pappas C. Free Web Conferencing Tools [online]. - Available from : http://elearningindustry.com/8-freeweb-conferencing-tools

11. Український інститут інформаційних технологій в освіті. Національний технічний університет України «Київський політехнічний інститут» [Електронний ресурс]. - Режим доступу : http://webinar.ipo.kpi.ua/.

12. Биков В. Ю.Електронні бібліометричні системи як засіб інформаційно-аналітичної підтримки науково-педагогічних досліджень / В. Ю. Биков, О.М.Спірін, Н.В.Сороко // Інформаційнокомунікаційні технології в сучасній освіті: досвід, проблеми, перспективи : зб. наук. праць. - Ч. 1. - Львів: ЛДУ БЖД, 2015. - С. 91-100.

Матеріал надійшов до редакиіï 15.06.2016 p.

\section{ИНФОРМАЦИОННО-АНАЛИТИЧЕСКАЯ ПОДДЕРЖКА НАУЧНО- ПЕДАГОГИЧЕСКИХ ИССЛЕДОВАНИЙ (ЗАРУБЕЖНЫЙ И ОТЕЧЕСТВЕННЫЙ ОПЫТ)}

\author{
Иванова Светлана Николаевна \\ кандидат педагогических наук, \\ заведующая отделом открытых образовательно-научных информационных систем \\ Институт информационных технологий и средств обучения НАПН Украины, г. Киев, Украина \\ iv-svetlana@yandex.ua
}




\begin{abstract}
Аннотация. В статье рассмотрен отечественный и зарубежный опыт информационноаналитической поддержки научно-педагогических исследований. Описана и охарактеризована структура информационно-аналитической поддержки Института информационных технологий и средств обучения Национальной академии педагогических наук Украины. Определено, что информационно-аналитическая поддержка научнопедагогической деятельности научно-исследовательских учреждений должна обеспечивать формирование базы данных; систематизацию и сохранение основных инновационных разработок научно-педагогических исследований; выявление перспективных направлений научных исследований; мониторинг научно-педагогических исследований; обнародование и распространение их продукции; свободный доступ к электронным образовательным ресурсам.
\end{abstract}

Ключевые слова: информационно-аналитическая поддержка; научно-педагогические исследования; мониторинг научно-педагогических исследований.

\title{
INFORMATION AND ANALYTICAL SUPPORT OF SCIENTIFIC AND PEDAGOGICAL RESEARCH (FOREIGN AND DOMESTIC EXPERIENCE)
}

\author{
Svitlana M. Ivanova \\ $\mathrm{PhD}$ (in Pedagogic), head of the Department of Open Education and Scientific Information Systems \\ Institute of Information Technologies and Learning Tools of NAES of Ukraine, Kyiv, Ukraine \\ iv-svetlana@yandex.ua
}

\begin{abstract}
The article deals with domestic and foreign experience of information and analytical support for scientific and educational research. There are described and characterized the structure of information and analytical support of the Institute of Information Technologies and Learning Tools of National Academy of Educational Sciences of Ukraine. Determined that the information and analytical support of scientific and educational activities of research institutions should provide database; systematization and preservation of the main innovation of scientific and educational research; identify promising areas of research; monitoring scientific and educational research; publication and dissemination of scientific production; free access to electronic educational resources.
\end{abstract}

Keywords: information and analytical support; scientific and educational research; monitoring scientific and educational research.

\section{REFERENCES (TRANSLATED AND TRANSLITERATED)}

1. Strategy for Information Society Development in Ukraine. Approved by Resolution of Cabinet of Ministers of 15 May 2013. № 386-p. [online]. - Available from : http://zakon0.rada.gov.ua/laws/show/386-2013-p. (in Ukrainian).

2. Chen J. A Structured Information Extraction Algorithm for Scientific Papers based on Feature Rules Learning / J. Chen, H. A. Chen // Journal of Software, Vol. 8, No. 1, January 2013. - Pp. 55-62 (in English).

3. Dursun Delen. Leveraging the capabilities of service-oriented decision support systems: Putting analytics and big data in cloud / Dursun Delen, Demirkan Haluk // Decision Support Systems 55. - 2013. - Pp. 412-421 (in English).

4. Information and analytical support of the university integrated information system: monograph / A.V. Vasiliev, V.V. Khomenko, V.A. Lyubchak, Yu.M. Korovaychenko, D.V. Filchenko. - Sumy : Sumy State University, 2013. - 126 p. (in Ukrainian).

5. Ivanova S.M. Information and analytical support for scientific activities in the field of educational sciences [online] / C. S.M. Ivanova // Information Technologies and Learning Tools. - 2015. - N 5 (49). - Pp. 165-175. - Available from : http://nbuv.gov.ua/UJRN/ITZN_2015_49_5_15 (in Ukrainian).

6. Ivanova S.M. Scientific Electronic Library NAES Ukraine as a means of information and analytical support educational research / S.M. Ivanova // Computer in school and family. - 2015 - № 6 - P. 11-15 (in Ukrainian).

7. Spirin O.M. Experience of digital library Academy of pedagogical sciences Ukraine/ O.Spirin, S.Ivanova // Ukrainian pedagogical journal. - 2015. - № 1. - Pp.192-205 (in Ukrainian). 
8. Yatsishin A.V. Experience with the system EDU Conference information support for scientific events in the field of pedagogical sciences [online] / A.V.Yatsishin // Scientific Conference Report of the Institute of Information Technologies and Learning Tools NAES Ukraine: Conference Materials. - Kyiv, Ukraine IITZN NAPS. - 2016. - Available from : http://conf.iitlt.gov.ua/Conference.php?h_id=12 (in Ukrainian).

9. Morze N.V. Methodical features of webinars, as an innovative technology of training [online] / N.V. Morze , A.V. Ignatenko //Information Technologies in Education. Kherson State University. - 2010. - № 5. - C. 31-39. - Available from : http://ite.kspu.edu/en/issue-5/p-31-39 (in Ukrainian).

10. Pappas C. Free Web Conferencing Tools [online]. - Available from : http://elearningindustry.com/8-freeweb-conferencing-tools (in English).

11. National Technical University of Ukraine "Kyiv Polytechnic Institute" [online]. - Available from : http://webinar.ipo.kpi.ua/ (in Ukrainian).

12. Bykov V. Yu. Electronic bibliometric system as a tool for information and analytical support of scientific and educational researches /V. Bykov, O. Spirin, N. Soroko // Information and communication technology in modern education: experience, problems and prospects. - 2015. - № 1. - Pp. 91-100. (in Ukrainian).

Conflict of interest. The author has declared no conflict of interest.

\section{(c) BY-NC-SA}

This work is licensed under Creative Commons Attribution-NonCommercial-ShareAlike 4.0 International License. 